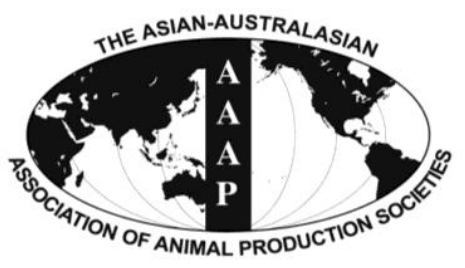

Asian Australas. J. Anim. Sci.

Vol. 26, No. 10 : 1379-1387 October 2013

http://dx.doi.org/10.5713/ajas.2013.13114

www.ajas.info

pISSN 1011-2367 elSSN 1976-5517

\title{
Association of Polymorphism Harbored by Tumor Necrosis Factor Alpha Gene and Sex of Calf with Lactation Performance in Cattle
}

\author{
N. S. Yudin ${ }^{1, *}$, R. B. Aitnazarov ${ }^{1}$, M. I. Voevoda ${ }^{2}$, L. A. Gerlinskaya ${ }^{3}$, and M. P. Moshkin ${ }^{1,4}$ \\ ${ }^{1}$ Institute of Cytology and Genetics, Siberian Branch of the Russian Academy of Sciences, \\ Novosibirsk 630090, Russian Federation
}

\begin{abstract}
In a majority of mammals, male infants have heavier body mass and grow faster than female infants. Accordingly, male offspring nursing requires a much greater maternal energy contribution to lactation. It is possible that the maternal-fetal immunoendocrine dialog plays an important role in female preparation for lactation during pregnancy. Immune system genes are an integral part of gene regulatory networks in lactation and tumor necrosis factor alpha (TNF $\alpha)$ is a proinflammatory cytokine that also plays an important role in normal mammary gland development. The aim of this study was to evaluate the influence of the sex of calf and/or the $-824 \mathrm{~A} / \mathrm{G}$ polymorphism in the promoter region of TNF $\alpha$ gene on milk performance traits in Black Pied cattle over the course of lactation. We also studied the allele frequency differences of $-824 \mathrm{~A} / \mathrm{G}$ variants across several cattle breeds, which were bred in different climatic conditions. The G allele frequency decreased gradually over the course of lactation events in the Black Pied dairy cattle because of a higher culling rate of cows with the $\mathrm{G} / \mathrm{G}$ genotype $(\mathrm{p}<0.001)$. In contrast to the genotypes $\mathrm{A} / \mathrm{A}$ and $\mathrm{A} / \mathrm{G}$, cows with G/G genotype showed significant variability of milk and milk fat yield subject to sex of delivered calf. Milk yield and milk fat yield were significantly higher in the case of birth of a bull calf than with a heifer calf $(\mathrm{p}<0.03)$. The $\mathrm{G}$ allele frequency varies from $48 \%$ to $58 \%$ in Grey Ukrainian and Black Pied cattle to $77 \%$ in aboriginal Yakut cattle. Our results suggest that the TNF $\alpha-824 \mathrm{~A} / \mathrm{G}$ gene polymorphism may have an influence on the reproductive efforts of cows over the course of lactation events depending on the sex of progeny. Allocation of resources according to sex of the calf allows optimizing the energy cost of lactation. This may be a probable reason for high $\mathrm{G}$ allele frequency in Yakut cattle breeding in extreme environmental conditions. Similarly, the dramatic fall in milk production after birth of a heifer calf increases the probability of culling for the cows with the G/G genotype in animal husbandry. (Key Words: Cattle, $T N F \alpha$ Gene, Single Nucleotide Polymorphism, Milk Production, Sex of Progeny)
\end{abstract}

\section{INTRODUCTION}

Sexual size dimorphism becomes apparent in heavier body mass of males in most mammal species (Lark et al., 2006). These differences are formed during prenatal development and increase during the ontogenesis (Loos et al., 2001). Accordingly, breastfeeding of male offspring requires a higher maternal investment in lactation.

\footnotetext{
* Corresponding Author: Nikolay Yudin. Tel: +7-383- 363-49-80, Fax: +7-383-333-12-78, E-mail: yudin@ bionet.nsc.ru

${ }^{2}$ Institute of Internal Medicine, Siberian Branch of the Russian Academy of Medical Sciences, Novosibirsk 630039, Russian Federation.

${ }^{3}$ Institute of Animal Systematics and Ecology, Siberian Branch of the Russian Academy of Sciences, Novosibirsk 630091, Russian Federation.

${ }^{4}$ Tomsk State University, Tomsk 634050, Russian Federation. Submitted Feb. 21, 2013; Accepted May 14, 2013; Revised May 22, 2013
}

Physiological lactation support depending on the sex of newborns occurs during pregnancy (Galbarczyk, 2011). Later the differences in milk productivity are caused by stronger breast stimulation of male offspring (CluttonBrock et al., 1981). Maternal organism receives information about the fetus male sex through the maternal immune response to HY fetal antigens (Nielsen, 2011). Intrauterine development is also regulated by different cytokines. Tumor necrosis factor alpha (TNF $\alpha)$ plays an important role in development of mammary gland (Warren et al., 2009), and inflammatory response of uterus after mating (Sanford et al., 1992). TNF $\alpha$ is abortifacient in high doses (Chaouat et al., 2007), but is necessary in low doses for the local tissue remodelling required for implantation (Chaouat et al., 2004). The possible function of TNF $\alpha$ may be to boost death signaling in order to kill the embryo if initial damages triggered by detrimental stimuli may culminate in structural anomalies, and stimulate protective mechanisms if the 
repair of these damages may prevent maldevelopment (Toder et al., 2003). The variability of milk traits according to sex of offspring can facilitate adaptive evolution in native mammals, but this variability may be a harmful factor for dairy cattle breeding. The aim of this study was to evaluate the influence of the sex of calf and the $-824 \mathrm{~A} / \mathrm{G} T N F \alpha$ genotypes on milk traits in Black Pied cattle and the allele frequency differences across domestic cattle populations. It was hypothesized that sex or genotype could influence milk production and selection can shift the allele frequencies.

\section{MATERIALS AND METHODS}

\section{Animals}

Blood samples of Black Pied breed $(n=107)$ were collected in the experimental farm "Elitnoe" of the Siberian Research Institute of Animal Husbandry SD RAAS (Novosibirsk region). The data on milk performance traits for each Black Pied cow were taken from breeding documentation. On the experimental farm "Elitnoe", lactating dairy cows were housed either in a free-stall barn or a pasture. The cows were milked twice a day. Automatic milking machines allowed obtaining milk yield data for each cow. The milk fat content was determined once a month. The milk yield, milk fat yield, and fat percentage were calculated by the A4/2 test interval method for the standard 305-d lactation length (ICAR, 2012). The calves were separated from their mothers within a day after their birth. After separation, young dairy calves subsisted on liquid milk, a commercial milk-replacer, or colostrum.

Blood samples of Grey Ukrainian breed $(n=48)$ and Yakut breed $(\mathrm{n}=33)$ were collected from an experimental agricultural farm of SB RAS (Altai Republic). Grey Ukrainian and Yakut cattle herds were raised at this experimental farm according to the conservation program of livestock genetic resources and were not used in milk production.

\section{Genotyping of DNA variants}

DNA was isolated by the standard methods using proteolytic treatment followed by phenol extraction. A fragment of 5'-flanking region of the bovine $T N F \alpha$ gene between positions 3090 and 3234 (GenBank accession no. Z14137) was amplified from genomic DNA by PCR with forward primer 5'-CCGAGAAATGGGACAACCT-3' and reverse primer 5'-GCCATGTATCCCCAAAGAAT-3'. The amplicon was digested with EcoICR I (SibEnzyme, Russia) and subsequently submitted to polyacrylamide gel analysis for the restriction fragment length polymorphism determination of the $-824 \mathrm{~A} / \mathrm{G}$ site. Genotype nomenclature refers to the respective SNP in position 3169 (GenBank accession no. Z14137). Fragment lengths were 81/64 bp for A/A homozygotes, 145 bp for $\mathrm{G} / \mathrm{G}$ homozygotes, and
145/81/64 bp for A/G heterozygotes.

\section{Statistical analysis}

Allele frequencies were calculated by direct counting. Allele frequencies were compared using contingency table $(2 \times 2)$ chi-square tests. Average numbers of lactations between genotypes were compared using nonparametric Kruskal-Wallis test. Associations of the SNP polymorphism $-824 \mathrm{~A} / \mathrm{G}$ in the promoter region of the bovine $T N F \alpha$ gene with milk performance traits were evaluated with analysis of covariance (ANCOVA, covarying for number of lactation episodes) using genotype and sex of the calf as independent variables. Post hoc analysis was performed with correction for multiple comparisons by Fisher's LSD test. Taking into consideration that after the fourth lactation there was less than $20 \%$ of initial livestock remaining, the milk performance traits were analyzed using the data from first to fourth lactations only. Since one cow could have several lactations in its lifetime, the number of genotypes exceeded the number of animals in the statistical analysis. The data were analyzed with the GLM procedure of STATISTICA 8.0 software.

\section{RESULTS}

No significant differences were observed in frequency of $\mathrm{G}$ allele of the $T N F \alpha-824 \mathrm{~A} / \mathrm{G}$ gene polymorphism between Grey Ukrainian (47.9\%) and Black Pied (57.9\%) cattle breeds. At the same time $\mathrm{G}$ allele frequency was increased to $77.3 \%$ in Yakut cattle breed. The $G$ allele frequency decreased gradually from $57.9 \%$ in primiparous heifers to $38.0 \%$ in fifth lactation and older cows of the Black Pied dairy herd which is likely due to differential culling of herd at the farm "Elitnoe" (Figure 1). This

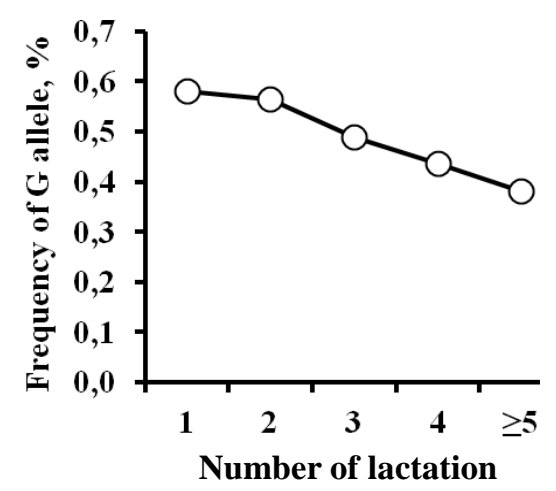

Figure 1. Temporal changes of the $G$ allele frequency of the $T N F \alpha-824 \mathrm{~A} / \mathrm{G}$ polymorphism per number of lactations in Black Pied cattle which is likely due to differential culling of herd. $\mathrm{n}=$ 31-107 animals per point. Significant differences in the G allele frequencies were observed between the first and fourth lactations $\left(x^{2}=4.02, \mathrm{p}<0.045\right)$ and between the first lactation and combining data for fifth and following lactations $\left(x^{2}=10.85, \mathrm{p}<0.02\right)$ as well. The $\mathrm{G}$ allele frequency was negatively correlated with number of lactation $\left(r_{\mathrm{s}}=-0.99, \mathrm{p}<0.002\right)$. 
decrease was due to frequency of the $\mathrm{G} / \mathrm{G}$ genotype decreasing faster than $\mathrm{A} / \mathrm{A}$ and $\mathrm{A} / \mathrm{G}$ genotypes (Figure 2). The average number of lactations during lifetime in cows with the $\mathrm{A} / \mathrm{A}, \mathrm{A} / \mathrm{G}$, and $\mathrm{G} / \mathrm{G}$ genotypes were $2.92 \pm 0.21$, $2.96 \pm 0.18$, and $1.99 \pm 0.13$, respectively. There was a highly significant difference among the three genotypes in this parameter (Kruskal-Wallis test $\mathrm{H}_{2,313}=14.89$, $\mathrm{p}<0.001$ ). The percentages of bull calves to heifer calves in cows with the $\mathrm{A} / \mathrm{A}, \mathrm{A} / \mathrm{G}$, and $\mathrm{G} / \mathrm{G}$ genotypes were $47.1 \%, 43.1 \%$, and $45.3 \%$, respectively.

The 305-d milk yield and milk fat yield increased from first to fourth lactation in cows of all genotypes (Figure 3A to $C)$. After fourth lactation, either a tendency to decrease or no further changes in milk yield and milk fat yield were observed. The percentage of fat didn't change significantly throughout the entire life spans of the cows. ANCOVA with number of lactation as a covariate was used to evaluate the

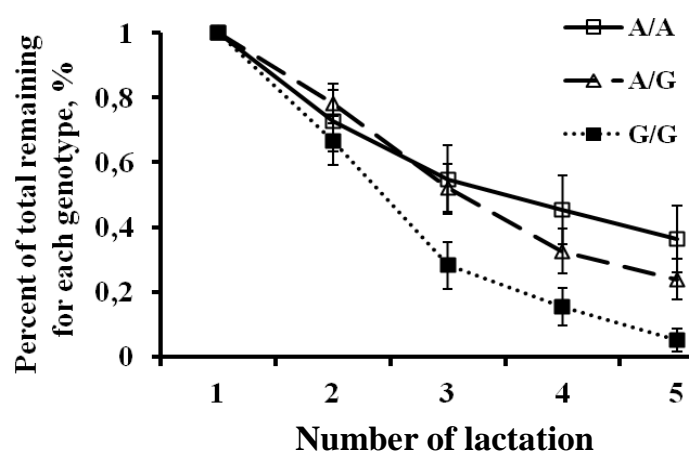

Figure 2. Temporal changes in the percent of total remaining for each $T N F \alpha-824 \mathrm{~A} / \mathrm{G}$ genotype per number of lactations in Black Pied cattle which is likely due to differential culling of herd. $n=2$ 46 animals per point. The standard error of the mean for genotype frequencies is displayed. The frequency for each genotype in primiparous heifers is taken as 100 percent.

D

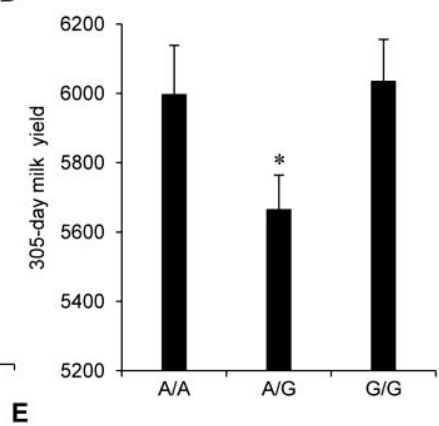

E

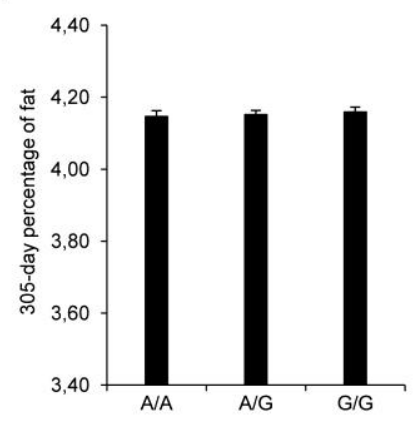

G

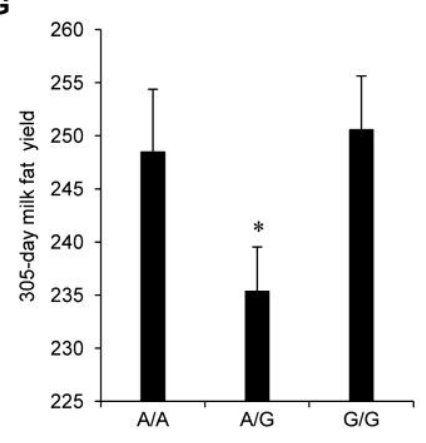

Figure 3. Data on milk performance traits in cows with different $T N F \alpha-824 \mathrm{~A} / \mathrm{G}$ genotypes. Data are reported as mean $\pm \mathrm{SEM}$. A, B, C: temporal changes of 305-d milk yield, 305-d percentage of fat, and 305-d milk fat yield, respectively; D, E, F: ANCOVA results for the same traits. Number of lactations is used as a covariate and data from first to fourth lactation are combined for ANCOVA. * p $<0.02$ relative to the G/G group corrected for multiple comparisons using Fisher's post-hoc LSD test. 
Table 1. Influence of genotype and sex of calf on milk performance traits in Black Pied cattle breed according to ANCOVA with number of lactation as a covariate

\begin{tabular}{llll}
\hline Factor & 305-d milk yield & 305-d percentage of fat & 305-d milk fat yield \\
\hline Genotype & $F_{2,255}=4.63, \mathrm{p}<0.01$ & $F_{2,255}=0.03, \mathrm{p}<0.97$ & $F_{2,255}=4.45, \mathrm{p}<0.01$ \\
Sex of calf & $F_{1,255}=2.51, \mathrm{p}<0.11$ & $F_{1,255}=0.08, \mathrm{p}<0.77$ & $F_{1,255}=2.27, \mathrm{p}<0.13$ \\
Intetraction genotype $\times$ sex & $F_{2,255}=5.07, \mathrm{p}<0.007$ & $F_{2,255}=1.99, \mathrm{p}<0.14$ & $F_{2,255}=4.70, \mathrm{p}<0.01$ \\
\hline
\end{tabular}

influence of sex of the calf and TNF $\alpha$ genotype on milk performance traits. The influence of a cow's genotype and genotype $\times$ sex of calf interaction on milk yield and milk fat yield has been established (Table 1). Milk yield and milk fat yield were significantly lower in heterozygotes for the $T N F \alpha-824 \mathrm{~A} / \mathrm{G}$ gene polymorphism compared to $\mathrm{G} / \mathrm{G}$ homozygotes $(\mathrm{p}<0.02)$ and had a tendency to decrease compared to A/A homozygotes $(\mathrm{p}<0.06)$ (Figure 3D to $\mathrm{G}$ ). At the same time sex of the calf alone didn't influence milk performance traits. But it had significant effect on these traits in interaction with cow's genotype (Table 1). It turned out that the milk yield and milk fat yield in cows with the G/G genotype were significantly higher in case of birth of a bull calf than that in case of birth of a heifer calf after correction for multiple comparisons (Figure 4A to C). Sex of the calf did not have an influence on milk performance traits in cows with the genotypes $\mathrm{A} / \mathrm{A}$ and $\mathrm{A} / \mathrm{G}$.

Sex of the calf could influence the milk performance
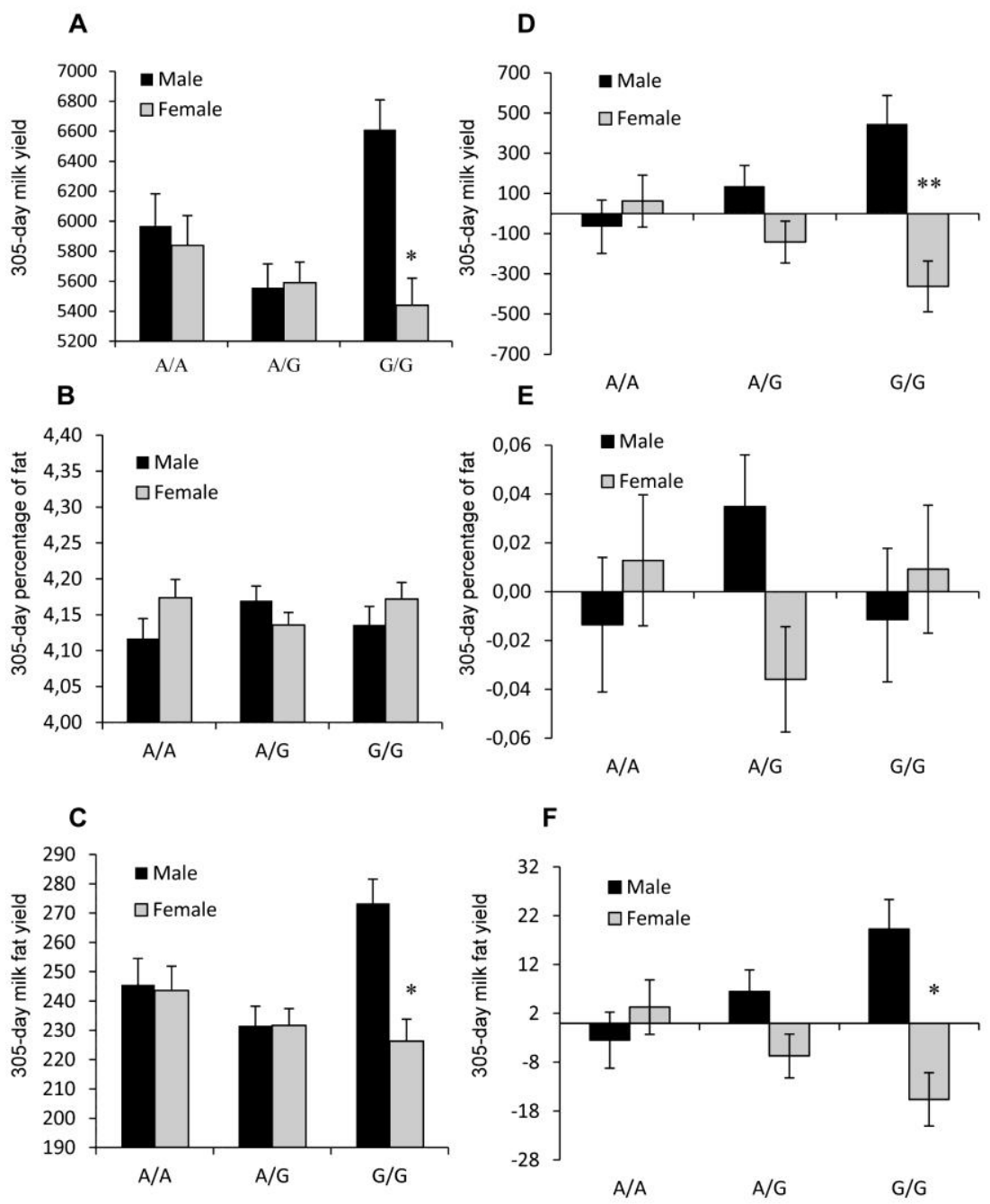

Figure 4. Influence of sex of the calf on the milk performance traits of cows with different $T N F \alpha-824 \mathrm{~A} / \mathrm{G}$ genotypes. Average data from first to fourth lactation are shown. Data are reported as mean \pm SEM. A, B, C: ANCOVA results for the 305-d milk yield, 305-d percentage of fat, and 305-d milk fat yield, respectively. Number of lactations is used as a covariate. D, E, F: ANCOVA analysis of residual variances of the same traits. ${ }^{*} \mathrm{p}<0.00004, * * \mathrm{p}<0.02$ relative to the bull calves corrected for multiple comparisons using Fisher's post-hoc LSD test. 
traits because cows that usually give birth to bull calves had higher milk yield and milk fat yield than cows that usually give birth to heifer calves. To answer the question of whether the cow's milk performance traits increase or decrease after giving birth to a bull or heifer calves, analysis of residual variances of milk performance data was performed with centering the variables around its means for the entire life spans of individual cows. Only data from the cows that had two and more lactations and delivered both bull and heifer calves were centered.

ANCOVA with number of lactation as a covariate showed that residual milk yields were significantly influenced by sex of the calf and genotype $\mathrm{x}$ sex interaction $\left(F_{1,133}=4.78, \mathrm{p}<0.03\right.$ and $F_{2,133}=2.11, \mathrm{p}<0.05$, respectively $)$. According to post hoc analysis, cows with the $G / G$ genotype showed significantly higher milk yield in case of birth of a bull calf than that in case of birth of a heifer calf after correction for multiple comparisons $(+447.4 \pm 152.8 \mathrm{~kg}$ and $-362.2 \pm 205.5 \mathrm{~kg}$, respectively) (Figure 4D). Sex of the calf and TNF $\alpha$ genotype didn't influence the percentage of fat. Residual milk fat yield, as well as residual milk yield, were significantly influenced by sex of the calf and genotype $\mathrm{x}$ sex interaction $\left(F_{1,133}=5.29, \mathrm{p}<0.02\right.$ and $F_{2,133}$ $=3.47, \mathrm{p}<0.03$, respectively). Cows with the $\mathrm{G} / \mathrm{G}$ genotype also showed significantly higher milk fat yield in case of birth of a bull calf than that in case of birth of a heifer calf after correction for multiple comparisons $(+19.3 \pm 6.2 \mathrm{~kg}$ and $-15.6 \pm 7.8 \mathrm{~kg}$, respectively) (Figure 4F).

\section{DISCUSSION}

The $T N F \alpha$ gene is present as a single copy gene 2,773 base pairs (bp) in length on bovine chromosome 23. The gene consists of four exons and three introns. mRNA product length is $1,713 \mathrm{bp}$. There are 28 single nucleotide polymorphisms (SNP) of bovine $T N F \alpha$ gene in the dbSNP database, but validation status for most of them is unknown (Sherry et al., 2001). Two SNP polymorphisms of TNFalpha gene in the exon and promoter regions were found to have a strong association with the early first ovulation after parturition in the high-producing dairy cows (Shirasuna et al., 2011). Since no effect of these polymorphisms on the gene function has not yet been proved, it may be possible that these markers are not functional variants, but may simply be in linkage disequilibrium with the true casual polymorphism(s). So far only one SNP $(-824 \mathrm{~A} / \mathrm{G})$ of $T N F \alpha$ gene was found may affect the functionality of the gene, since it influences the transcriptional promoter activity in vitro (Konnai et al., 2006). Moreover, the frequency of $-824 \mathrm{G}$ allele was higher in individuals with bovine leukemia virus (BLV) induced lymphoma than in asymptomatic carrier individuals. Thus $-824 \mathrm{~A} / \mathrm{G}$ SNP has been genotyped in our study.
We studied the frequency of this SNP among several cattle breeds, which were bred in different climatic conditions. The Yakut cattle live above the Arctic Circle at all times (Granberg et al., 2009). Yakut cows have low milkability but high resistance to the hardest Arctic conditions, where winter temperature drops up to $-60^{\circ} \mathrm{C}$ and summer temperatures reaches $+40^{\circ} \mathrm{C}$. During 10 months temperatures remain below zero. In winter the cattle are kept in unheated cowsheds and even at the temperature $-50^{\circ} \mathrm{C}$, the cattle are sent to drink from ice-holes. Grey Ukrainian cattle initially were a breed meant for producing meat and working the fields: it could work for $12 \mathrm{~h}$ straight in the fields. In 1917, it was recognized as the best beef breed in Russia. Currently, around 100 head of these cattle are conserved in Siberia. Ecophysiological and molecular phylogenetic characteristics also indicate a close relationship of aboriginal Yakut and Grey Ukrainian cattle to the aurochs (Semenova et al., 2000; Kantanen et al., 2009). Before domestication aurochs were widespread in Eurasia from the Scandinavian peninsula in the north to Northern Africa in the south (van Vuure 2005), and probably they were well adapted to the harsh environment. Black Pied breed is the major breed of dairy cattle utilized in milk production in the Russia.

Our study of Russian cattle breeds shows that $\mathrm{G}$ allele frequencies of the $T N F \alpha-824 \mathrm{~A} / \mathrm{G}$ gene polymorphism in Grey Ukrainian and Black Pied breeds are $47.9 \%$ and $57.9 \%$ respectively. These values are in good agreement with previously reported value of $51.9 \%$ for Japanese black and Holstein-Friesian cattle breeds (Konnai et al., 2006). Difference in $\mathrm{G}$ allele frequency between the breeds can be explained by genetic drift and founder effect, because the effective population size during breed development usually is small. The aboriginal Yakut cattle breed in our study had high frequency of $\mathrm{G}$ allele - 77.0\%. Yakut cattle is welladapted to extreme climates and closely related to the wild ancestor of domestic cattle - the aurochs (Bos primigenius) (Kantanen et al., 2009).

The sex ratios of bull calves to heifer calves in cows with the $\mathrm{A} / \mathrm{A}, \mathrm{A} / \mathrm{G}$, and $\mathrm{G} / \mathrm{G}$ genotypes were $47.1 \%, 43.1 \%$, and $45.3 \%$, respectively. These ratios did not differ significantly from the overall secondary ratios (at birth) nor in Bos taurus (51.52\%) (Asdell, 1964), nor in Bison bonasus (49.2\%) (Jaczewski, 1958). Analyzing age specific variation of the $T N F \alpha-824 \mathrm{~A} / \mathrm{G}$ gene polymorphism, we have found that the $\mathrm{G}$ allele frequency decreased gradually over the course of lactation events. In addition, the average numbers of lifetime lactations in cows with the G/G genotype were one-and-a-half times lower than that in cows with the genotypes $\mathrm{A} / \mathrm{A}$ and $\mathrm{A} / \mathrm{G}$. This is possible only if cows with the $\mathrm{G} / \mathrm{G}$ genotype have a higher culling rate. But what is the cause of such high culling rate, which leads to decrease of $\mathrm{G}$ allele frequency in dairy herds compared with 
domestic low yielding cows such as Yakut cattle?

Although domestic cows can live for 20 yrs, those raised for dairy rarely live that long, as the average cow is removed from the dairy herd around age four and marketed for beef (Ng, 2001; Wallace, 2002). On most dairy farms, annual culling rates exceed $30 \%$ of the herd. These animals are culled mainly due to low milk production or infectious diseases (mastitis). As to susceptibility to infectious diseases, it was reported that the frequency of the $G$ allele of the $T N F \alpha-824 \mathrm{~A} / \mathrm{G}$ gene polymorphism was higher in individuals with BLV-induced lymphoma than in asymptomatic carrier individuals (Konnai et al., 2006). Similarly, these authors observed a tendency for increased provirus load in cattle with G/G homozygote compared to A/A homozygote or A/G heterozygote. These data suggest that the $T N F \alpha-824 \mathrm{~A} / \mathrm{G}$ gene polymorphism could at least in part contribute to the progression of lymphoma in BLV infection. BLV is one of the most common infectious viruses of cattle with a worldwide distribution. BLV infected cows have a higher culling rate due to higher susceptibility to opportunistic and infectious agents (mastitis, lameness diseases, ringworm infection etc.), decreased productivity, and lower reproductivity (Rodriguez et al., 2011).

As to low milk production, it is necessary to note that if the cow's yearly estimated milk production level is $20 \%$ or more below the herd's average it may be enough justification to base a culling decision (Small Farm Resource, 2002). According to our data, cows with the G/G genotype are characterized by considerable variation of the milk yield and milk fat yield between lactations in contrast to $\mathrm{A} / \mathrm{A}$ homozygote or $\mathrm{A} / \mathrm{G}$ heterozygote, in which sex of the calf didn't influence on milk performance traits (Figure 4). The milk yield and milk fat yield of cows with the G/G genotype were decreased by almost $17 \%$ in case of birth of a heifer calf than that in case of birth of a bull calf. It is clear that such a decrease in milk production after birth of a heifer calf increases the probability of culling of the cow.

The reason for variation in milk yield and milk fat yield that depends on the sex of calves may be a kind of dialogue that goes on during pregnancy between the mother and her unborn baby. This dialogue prepares the mother for lactation that is adequate for the physiological needs of newborn calves. Genotype-restricted influences of sex on milk performance traits take place only in cows with the G/G genotype. Our analysis of residual variances of milk yield, percentage of fat, and milk fat yield over the entire life span of individual cows confirmed the contribution of fetal sex to variation in the milk production traits. According to the analysis of residual variances, lactations following the birth of a heifer calves were characterized by lower milk productivity in comparison with the corresponding individual average value for the entire life span of the cow. Similarly, the milk production following the birth of a bull calf exceeds the individual's lifetime mean. These differences in lactation in response to the sex of newborn calf relate only to milk and milk fat yield. Sex of the calf didn't influence the percentage of milk fat. Thus, analysis of residual variances of milk performance data shows that the sex of progeny significantly influences preparation of the mother for lactation.

In a majority of mammals, male infants grow faster and demand increasing milk production from their mothers (Lark et al., 2006). It is possible that a male fetus prepares the mother's body for more intensive lactation already during intrauterine development. As this effect was observed in cows with the $\mathrm{G} / \mathrm{G}$ genotype only, it seems most likely that signal transduction in the "mother-fetus" system occurs by HY antigens-induced mother's immune responses. It is known that several widely expressed genes on the $\mathrm{Y}$ chromosome code for male-specific proteins that provoke an immune reaction in mothers (Graves, 2010). $\mathrm{TNF} \alpha$ is known to induce a normal mammary gland development, but at the same time it is also able to induce apoptotic cell death (Locksley et al., 2001). The mean transcriptional promoter activity is significantly decreased in $-824 \mathrm{G}$ promoter compared to $-824 \mathrm{~A}$ promoter of the cattle $T N F \alpha$ gene in vitro (Konnai et al., 2006). In these terms, probable low TNF $\alpha$ production in cows with the $\mathrm{G} / \mathrm{G}$ genotype may enhance the number of mammary epithelial cells. Finally decreased TNF $\alpha$ production may also be involved in the modulation of Th1/Th2 balance during maternal immune response to HY antigens (Herman et al., 2011).

Allocation of resources according to needs of male and female progeny in cows with the $\mathrm{G} / \mathrm{G}$ genotype may improve reproductive fitness of wild cattle species. This idea is supported indirectly by its high frequency in the Yakut cattle, living in extreme Arctic conditions with extremely cold winter and high ectoparasite (mosquito etc.) burden in summer.

The efficiency of infant suckling and milk removal governs the milk volume produced in the udder. Observations show that male calves suck from their mothers more frequently than female calves (Clutton-Brock et al., 1981). But in dairy farms calves are separated from their mothers immediately after birth and are fed with artificial food (More et al., 2010). In particular, this practice takes place in the experimental farm "Elitnoe" where our study was carried out. Other authors found that the sex of offspring had no effect on milk yield (Wohlt et al., 1984). But they didn't take into consideration possible influence of genetic factors and calf nursing behavior on this trait.

Another reason for different milk production among $\mathrm{G} / \mathrm{G}$ individuals that is correlated with the sex of the calf may be the stable individual differences in milk 
performance traits among cows. For example, more productive cows may more often give birth to bull calves. Actually in humans, the mothers of boys are heavier in pregnancy than the mothers of girls and have a higher body mass index (Alwasel et al., 2011). However the analysis of residual variances of milk performance data with centering the variables around its means for the entire life spans of individual cows disprove this hypothesis.

Dramatic changes in cell composition and function occur in the mammary gland during a pregnancy-lactationinvolution cycle. Immune system genes are an integral part of gene regulatory networks in lactation. Milk contains a variety of innate defense factors and cellular components that provide both protection against infections and allergies and it also stimulates the appropriate development of the infant's own immune system. Immune genes expressed in mammary tissue during pregnancy appear to participate in mammary gland development (Faucon et al., 2009; Watson, 2009). Some genes that have been annotated with respect to positive regulation of lymphocyte proliferation and cytokine biosynthesis are important to the development of the mammary gland during late pregnancy. However, genes associated with such terms as 'antigen processing' or 'antigen presentation' are statistically down-regulated during lactation relative to late pregnancy (Lemay et al., 2007). Postlactational regression (phagocytosis of cell debris and milk droplets) is associated with a phase of acute inflammatory response, in addition to cell death (Atabai et al., 2007; Watson, 2009). This is consistent with the original idea that the mammary gland evolved from the innate immune system (Vorbach et al., 2006).

An association of immune system genes with reproductive traits of livestock animals may be considered in two respects. First, there may be a positive correlation between immune responses and these traits, because of animal breeding in the presence of pathogens that would favor improving reproductive traits mostly in the genetically resistant animals. Secondly, the correlation may be negative if a trade-off between immune function and reproductive efforts is involved. It is obvious that developing and maintaining an effective immune system under parasite challenge may be costly and result in reduced secondary sexual (reproductive) traits (van der Most et al., 2011). Unfortunately, there are only few studies analyzing the associations of polymorphisms in immune genes with reproductive traits in livestock animals. For example, the association of lymphoid enhancer-binding factor-1 (LEF1) gene with the number of functional and inverted teats in pigs was described (Tetzlaff et al., 2009). The association of the proliferation associated nuclear element 1 (PANE1) gene encoding one of the minor histocompatibility antigens with the hematological immune traits influences the birth weight in pigs (Huang et al., 2010). The association of SNPs in the chemokine CCL2 and caspase recruitment domain CARD15 genes with milk production traits was found in Canadian Holstein cattle (Leyva-Baca et al., 2007; Pant et al., 2007). Other authors reported the associations of SNPs in Toll-like Receptor 4 (TLR-4) gene, chemokine receptor 1 (CXCR1) gene, $C D 14$ gene, and serum protease inhibitor (SERPINA1) gene with milk production in dairy cattle (Beecher et al., 2010). This conceptual framework clearly warrants further investigation.

We also observed the low milk yield and milk fat yield in $\mathrm{A} / \mathrm{G}$ heterozygotes compared to both $\mathrm{A} / \mathrm{A}$ and $\mathrm{G} / \mathrm{G}$ homozygotes, i.e. so-called underdominance effect. Other authors described a similar underdominance for some reproductive traits in cattle (Lin et al., 1987). The cause of this phenomenon is unclear, but it may suppose that reduced milk production in heterozygotes results in higher relative fitness (heterozygous advantage), possibly increasing survival rates in harsh environment.

In conclusion, we found evidence that the TNF $\alpha$ $824 \mathrm{~A} / \mathrm{G}$ gene polymorphism is associated with the lactation shift subsequent to delivery of male or female calf in domestic cattle. If allocation of resources according to sex of the calf allows optimizing the energy cost of lactation, it may result in positive selection of the $G$ allele in domestic cattle breeding in extreme environmental conditions. In the same way, if the dramatic fall in milk production after birth of a heifer calf increases the probability of culling for the cows with the G/G genotype in animal husbandry, it may result in negative selection of the $G$ allele during the subsequent lactations in dairy cattle herds. As regards the importance of our results to milk industry it seems reasonable to improve of cattle herds by selection in favor of A/A homozygotes. In addition to resistance to bovine leukemia, milk performance traits of cows with the A/A genotype are independent of from sex of newborn calf.

\section{ACKNOWLEDGEMENTS}

This project was partially supported by the Russian Foundation for Basic Research (Grant No. 13-04-00968) and the Expeditionary Grant of SD RAS (No. 2012-21-3). We are grateful to Anatoly Kushnir for help in sample collection. Special appreciation goes to Prof. William Lidicker for valuable comments on the manuscript.

\section{REFERENCES}

Alwasel, S. H., Z. Abotalib, J. S. Aljarallah, C. Osmond, S. M. Alkharaz, I. M. Alhazza, A. Harrath, K. Thornburg, and D. J. Barker. 2011. Sex differences in birth size and intergenerational effects of intrauterine exposure to Ramadan in Saudi Arabia. Am. J. Hum. Biol. 23:651-654.

Asdell, S. A. 1964. Patterns of mammalian reproduction. Cornell University Press, New York. 
Atabai, K., D. Sheppard, and Z. Werb. 2007. Roles of the innate immune system in mammary gland remodeling during involution. J. Mammary Gland Biol. Neoplasia 12:37-45.

Beecher, C., M. Daly, S. Childs, D. P. Berry, D. A. Magee, T. V. McCarthy, and L. Giblin. 2010. Polymorphisms in bovine immune genes and their associations with somatic cell count and milk production in dairy cattle. BMC Genetics 11:99.

Chaouat, G., N. Ledee-Bataille, S. Dubanchet, S. Zourbas, O. Sandra, and J. Martal. 2004. TH1/TH2 paradigm in pregnancy: paradigm lost? Cytokines in pregnancy/early abortion: reexamining the $\mathrm{TH} 1 / \mathrm{TH} 2$ paradigm. Int. Arch. Allergy Immunol. 134:93-119.

Chaouat, G., S. Dubanchet, and N. Ledee. 2007. Cytokines: Important for implantation? J. Assist. Reprod. Genet. 24:491505.

Clutton-Brock, T. H., S. D. Albon, and F. E. Guinness. 1981. Parental investment in male and female offspring in polygynous mammals. Nature 289:487-489.

Faucon, F., E. Rebours, C. Bevilacqua, J. C. Helbling, J. Aubert, S. Makhzami, S. Dhorne-Pollet, S. Robin, and P. Martin P. 2009. Terminal differentiation of goat mammary tissue during pregnancy requires the expression of genes involved in immune functions. Physiol. Genomics 40:61-82.

Galbarczyk, A. 2011. Unexpected changes in maternal breast size during pregnancy in relation to infant sex: an evolutionary interpretation. Am. J. Hum. Biol. 23:560-562.

Granberg, L., K. Soini, and J. Kantanen. 2009. Sakha Ynaga-cattle of the Yakuts. Finnish Academy of Science and Letters, Helsinki.

Graves, J. A. 2010. Review: Sex chromosome evolution and the expression of sex-specific genes in the placenta. Placenta 31:S27-S32.

Herman, S., N. Zurgil, S. Machlav, A. Shinberg, P. Langevitz, M. Ehrenfeld, and M. Deutsch 2011. Distinct effects of anti-tumor necrosis factor combined therapy on $\mathrm{TH} 1 / \mathrm{TH} 2$ balance in rheumatoid arthritis patients. Clin. Vaccine Immunol. 18:10771082 .

Huang, H., H. Deng, Y. Yang, Z. Tang, S. Yang, Y. Mu, W. Cui, J. Yuan, Z. Wu, and K. Li. 2010. Molecular characterization and association analysis of porcine PANE1 gene. Mol. Biol. Rep. 37:2571-2577.

Jaczewski, Z. 1958. Reproduction of the European bison, Bison bonasus (L.), in reserves. Acta Theriol. 1:333-376.

ICAR. 2012. International Committee for Animal Recording. International agreement on recording practices.

Kantanen, J., C. J. Edwards, D. G. Bradley, H. Viinalass, S. Thessler, Z. Ivanova, T. Kiselyova, M. Cinkulov, R. Popov, S Stojanović, I. Ammosov, and J. Vilkki. 2009. Maternal and paternal genealogy of Eurasian taurine cattle (Bos taurus). Heredity 103:404-415.

Konnai, S., T. Usui, M. Ikeda, J. Kohara, T. Hirata, K. Okada, K. Ohashi, and M. Onuma. 2006. Tumor necrosis factor-alpha genetic polymorphism may contribute to progression of bovine leukemia virus-infection. Microbes Infect. 8:2163-2171.

Lark, K. G., K. Chase, and N. B. Sutter. 2006. Genetic architecture of the dog: sexual size dimorphism and functional morphology. Trends Genet. 22:537-544.

Lemay, D. G., M. C. Neville, M. C. Rudolph, K. S. Pollard, and J. B. German. 2007. Gene regulatory networks in lactation: identification of global principles using bioinformatics. BMC Syst. Biol. 1:56.

Leyva-Baca, I., F. Schenkel, B.S. Sharma, G. B. Jansen, and N. A. Karrow. 2007. Identification of single nucleotide polymorphisms in the bovine CCL2, IL8, CCR2 and IL8RA genes and their association with health and production in Canadian Holsteins. Anim. Genet. 38:198-202.

Lin, C. Y., A. J. McAllister, K. F. Ng-Kwai-Hang, J. F. Hayes, T. R. Batra, A. J. Lee, G. L. Roy, J. A. Vesely, J. M. Wauthy, and K. A. Winter. 1987. Association of milk protein types with growth and reproductive performance of dairy heifers. J. Dairy Sci. 70:29-39.

Locksley, R. M., N. Killeen, and M. J. Lenardo. 2001. The TNF and TNF receptor superfamilies: integrating mammalian biology. Cell 104:487-501.

Loos, R. J., C. Derom, R. Eeckels, R. Derom, and R. Vlietinck, 2001. Length of gestation and birthweight in dizygotic twins. Lancet 358:560-561.

More, D., K. Heaton, S. Poisson, and W. Sischo. 2010. The Calf's First Environment - The Maternity Pen. Accessed Feb. 12, 2013. http://vetextension.wsu.edu/documents/CalfEnv1MaternityPen.pdf.

Ng, J. 2001. Animal diversity web. Accessed Feb. 12, 2013. http://animaldiversity.ummz.umich.edu/site/accounts/informati on/Bos_taurus.html.

Nielsen, H. S. 2011. Secondary recurrent miscarriage and H-Y immunity. Hum. Reprod. Update 17:558-574.

Pant, S. D., F. S. Schenkel, I. Leyva-Baca, B. S. Sharma, and N. A. Karrow. 2007. Identification of single nucleotide polymorphisms in bovine CARD15 and their associations with health and production traits in Canadian Holsteins. BMC Genomics 8:421.

Rodriguez, S. M., A. Florins, N. Gillet, A. de Brogniez, M. T. Sanchez-Alcaraz, M. Boxus, F. Boulanger, G. Gutiérrez, K. Trono, I. Alvarez, L. Vagnoni, and L. Willems. 2011. Preventive and therapeutic strategies for bovine leukemia virus: lessons for HTLV. Viruses 3:1210-1248.

Sanford, T. R., M. De, and G. W. Wood. 1992. Expression of colony-stimulating factors and inflammatory cytokines in the uterus of CD1 mice during days 1 to 3 of pregnancy. J. Reprod. Fertil. 94:213-220.

Semenova, S. K., V. A. Vasil'ev, E. V. Morozova, A. V. Slyn'ko, E. P. Steklenev, I. P. Belousova, I. V. Kudriavtsev, and A. P. Ryskov. 2000. DNA fingerprinting and genetic diversity of the European bison (Bison bonasus), American bison (Bison bison), and gray Ukrainian cattle (Bos taurus). Genetika 36:1535-1545 (In Russian).

Sherry, S. T., M. H. Ward, M. Kholodov, J. Baker, L. Phan, E. M. Smigielski, and K. Sirotkin. 2001. dbSNP: the NCBI database of genetic variation. Nucl. Acids Res. 29:308-311.

Shirasuna, K., C. Kawashima, C. Murayama, Y. Aoki, Y. Masuda, K. Kida, M. Matsui, T. Shimizu, and A. Miyamoto. 2011. Relationships between the first ovulation postpartum and polymorphism in genes relating to function of immunity, metabolism and reproduction in high-producing dairy cows. J. Reprod. Dev. 57:135-142.

Small Farm Resource. 2002. Culling dairy cows. Accessed Feb. 12, 2013. http://www.farminfo.org/dairy/culling.htm.

Tetzlaff, S., E. Jonas, C. Phatsara, E. Murani, S. Ponsuksili, K. 
Schellander, and K. Wimmers. 2009. Evidence for association of lymphoid enhancer-binding factor-1 (LEF1) with the number of functional and inverted teats in pigs. Cytogenet. Genome Res. 124:139-146.

Toder, V., A. Fein, H. Carp, and A. Torchinsky. 2003. TNF-alpha in pregnancy loss and embryo maldevelopment: a mediator of detrimental stimuli or a protector of the fetoplacental unit? J. Assist. Reprod. Genet. 20:73-81.

van der Most, P. J., B. de Jong, H. K. Parmentier, and S. Verhulst. 2011. Trade-off between growth and immune function: a metaanalysis of selection experiments. Funct. Ecol. 25:74-80.

van Vuure, C. 2005. Retracing the aurochs: History, morphology and ecology of an Extinct Wild Ox. Pensoft Publishers, SofiaMoscow.
Vorbach, C., M. R. Capecchi, and J. M. Penninger. 2006. Evolution of the mammary gland from the innate immune system? Bioessays 28:606-616.

Wallace, R. 2002. Market Cows: A Potential Profit Center. Accessed Feb. 12, 2013. http://www.livestocktrail.uiuc.edu/ dairynet/paperdisplay.cfm?contentid $=354$.

Warren, M. A., S. F. Shoemaker, D. J. Shealy, W. Bshar, and M. M. Ip. 2009. Tumor necrosis factor deficiency inhibits mammary tumorigenesis and a tumor necrosis factor neutralizing antibody decreases mammary tumor growth in neu/erbB2 transgenic mice. Mol. Cancer Ther. 8:2655-2663.

Watson, C. J. 2009. Immune cell regulators in mouse mammary development and involution. J. Anim. Sci. 87:35-42.

Wohlt, J. E., W. L. Foy, D. M. Kniffen, and J. R. Trout. 1984. Milk yield by Dorset ewes as affected by sibling status, sex and age of lamb, and measurement. J. Dairy Sci. 67:802-807. 